\title{
Chronically Happy
}

\section{Awo Onwudiwe}

The Ohio State University, Columbus, $\mathrm{OH}$, USA.

KEY WORDS: chronic disease; self-care; self-management; quality of life; vulnerable populations.

J Gen Intern Med 34(1):161-2

DOI: $10.1007 / \mathrm{s} 11606-018-4684-3$

(c) Society of General Internal Medicine 2018

$\mathrm{M}$ y earliest memory of having sickle cell was in second grade. It was my first case of acute chest. I was hospitalized for a week, the longest I had ever been admitted. I remember being scared of the IVs and oxygen tubes. After returning to school, I noticed my classmates treated me differently. Some asked a lot of questions, others did not talk to me at all. I did not like the change and decided to ignore it all together.

In third grade, we did a project on diseases and I chose sickle cell. The main fact I learned from the project was sickle cell is a hereditary disease. I remember being mad at my parents. Why did they do this to me? Why was I the only one in the family with sickle cell?

Elementary school was also the first time I felt stigmatized for having sickle cell. One day, a boy backed away as I was walking by him. Confused, I asked why and he told me he did not want to catch my disease. I was mortified, I could not believe how ignorant he was, and I was afraid everyone thought I was a contagious, diseased girl. After several encounters with him, I became ashamed. I stopped talking to people about sickle cell altogether because I did not want everyone to see me differently. I would tell my friends I was sick with a fever instead of telling them the truth. I was afraid of being pitied. I talk about it with friends I met at a camp for kids with chronic diseases. Even then, it is hard to discuss my struggles. The only people I am truly comfortable talking to are my mom and doctor.

Thankfully, my disease is not considered severe but the summer of 2017 was unusual. I went to Paris to visit my aunt for two weeks. It was my first time traveling out of America by myself. I did most of the sightseeing alone and the first week was amazing. I visited many attractions and enjoyed French cuisine. That weekend we traveled to my aunt's friend's beach house. On the first night, I woke up with mild back pain, which shot to a seven out of ten after my feet hit the cold floor. It was at this time that I remembered I left my medications in Paris. Instead of asking for help I dealt with the pain and barely got any sleep that night.

Published online October 3, 2018
I was in severe pain by the morning. I felt embarrassed that I forgot to bring my medicines. I finally cracked and told my aunt; she immediately called my mom who told her the medication to buy. I spent that day lying out in the sun, since I had no heating pad. Even though I was sick, I kept a smile on my face. By the time we left, most of the pain had subsided, and I was ready for the rest of my trip.

My last week in Paris was cut short after a visit to the catacombs. By the end of the visit, I felt cold and tired. As the day progressed, my chest hurt and I was short of breath so my aunt took me to the ER and I was admitted.

This was my first admission to an adult hospital. It was scary. There were no fun decorations or colorful walls. Language was the major barrier. None of the nurses or doctors spoke English, and I speak only basic French. My aunt translated to the best of her abilities but many words got lost in translation. I was upset my mom wasn't there. She always explains what the doctors mean and helps ease my worries. It was hard to be in the hospital without her. I traveled back home the day after I was discharged.

A week after I returned, I was admitted again with knee pain, just days before a family trip to Houston for a wedding. My mom suggested not going but I did not want to miss it. I was discharged on crutches since walking made my knee worse. I was frustrated and constantly in pain. The crutches only made it worse because I felt helpless. Even with these challenges, I enjoyed the trip and am glad I went.

In fall 2018, I will be a freshman in a college an hour and a half away from home. I am independent when it comes to taking my daily medications and controlling mild pain. I may have to go to a hospital alone. Although I think that my mom and doctors have prepared me well for living with sickle cell as an adult, a part of me is fearful.

Sickle cell is my normal. I would love to live in a world where I did not have it. It would be great to not have to take medication every day. I used to think everyone had doctor's appointments and blood drawn every few months. I am like most teenagers, I just happen to have sickle cell. If I spent time wishing I was healthy, I would not enjoy life and would have a pessimistic view on life. I choose to live as best I can, because sickle cell should not hold me back. It is a challenge in my life, but I refuse to accept defeat; I always fight back.

Recently, someone asked me how I cope with sickle cell. I gave them a vague answer, but the question stuck with me. I think I cope because it is all I have ever known. Being 
born with a disease is a lot different than acquiring one later in life. I also cope because I know things could be worse. I cope for these reasons but they are not the reason. I realized the answer is in the question itself; I cope. What other choice do I have?
Corresponding Author: Awo Onwudiwe, The Ohio State University, Columbus, OH, USA (e-mail: ONWUDIWE.3@OSU.EDU).

Compliance with Ethical Standards:

Conflicts of Interest: None. 